University for Business and Technology in Kosovo

UBT Knowledge Center

Nov 2nd, 9:00 AM - Nov 3rd, 5:00 PM

\title{
Research of Agronomic and Quality Traits of Winter Barley Varieties (Hordeum vulgare L.) under Growing Conditions in the Republic of Kosovo
}

\author{
Nexhdet Shala \\ Institute of Agriculture, Kosovo, ismajlcacaj@yahoo.com \\ Bakir Kelmendi \\ Institute of Agriculture, Kosovo, bakir222@yahoo.com
}

Follow this and additional works at: https://knowledgecenter.ubt-uni.net/conference

Part of the Computer Sciences Commons, and the Engineering Commons

\section{Recommended Citation}

Shala, Nexhdet and Kelmendi, Bakir, "Research of Agronomic and Quality Traits of Winter Barley Varieties (Hordeum vulgare L.) under Growing Conditions in the Republic of Kosovo" (2012). UBT International Conference. 69.

https://knowledgecenter.ubt-uni.net/conference/2012/all-events/69

This Event is brought to you for free and open access by the Publication and Journals at UBT Knowledge Center. It has been accepted for inclusion in UBT International Conference by an authorized administrator of UBT Knowledge Center. For more information, please contact knowledge.center@ubt-uni.net. 


\title{
Research of Agronomic and Quality Traits of Winter Barley Varieties (Hordeum vulgare L.) under Growing Conditions in the Republic of Kosovo
}

\author{
Nexhdet Shala ${ }^{1 *}$, Bakir Kelmendi ${ }^{2}$ \\ ${ }^{1}$ Technologist in Producing Brewery, Sh. A."Birra Peja” Rr. N. Basha 160, 30000 Peja, Kosova \\ ${ }^{2}$ Institute of Agriculture Kosovo - Peja, Rr. Adem Jashari, 30000 Peja, Kosova \\ ${ }^{3}$ Institute of Agriculture Kosovo - Peja, Rr. Adem Jashari, 30000 Peja, Kosova \\ 1nnshala1@ hotmail.com ; ${ }^{2}$ bakir222@y ahoo.com ; ${ }^{3 \text { ismajlcacaj@yahoo.com }}$
}

\begin{abstract}
The object of this paper is the research of agronomic and quality trains of winter varieties (hordeum vulgare L.) their adaptability and specific reactions towards growing conditions in the Republic of Kosovo. During three year trails on localities in Dukagjini area and area of Kosovo we researched 5 winter barley varieties. Environment has been explored together with estimation of significant parameters of grain yield, hectoliter weight, protein and starch content. Impact of year, location and variety on grain yield, hectoliter grain weight, protein and starch content has been estimated by analysis of variance. Environmental effects of planting barley cultivars in the Dukagjini area and area of Kosovo is based on a study that determines the influence of climatic factors, temperature and moisture, the quality of barley for beer production. Experiments were set according to the method of randomized blocks in three repetitions. Area of each experimental plot was $10 \mathrm{~m} 2$. In the laboratory at the Agricultural Institute of Kosovo, and close laboratory brewery in Peja were analyzed: the content of protein (\%), weight (1000 seeds in grams), hectoliters weight $(\mathrm{kg})$, humidity $(\%)$, yield $(\mathrm{kg} / \mathrm{ha})$, starch, color, aroma, impurity. Results obtained showed that parameters of achieved grain yield show that under favorable growing conditions one can expect better results of varieties Zllatko, Barun and Vanesa.
\end{abstract}

Key words: barley, variety, grain yield, quality.

1.

Introduction

Study in the field of evaluation of new cultivars of interest in agricultural research. Barley in Kosovo, it is culture that planted every year to meet the necessary requirements of manufactures for high yield, quality and many other factors necessary for high yield, quality and many other factors for maltim as raw material for the production of beer, it is necessary cultivars research new to growing conditions in the Repub lic of Kosovo $[4,10]$. Kosovo has very good agronomic conditions for the cultivation of this crop. Barley is a plant in Europe occupies an important place in the structure of the cultivated plants. In our country, the years of transition, there was a significant reduction of the area planted with barley. Changing the structure of the variety that has come as a result of planting new varieties, has necessitated a study of the suitability of these varieties associated with different climatic conditions in Koso vo $[15,16]$. This adaptability not only see the impact of climatic conditions in different varieties manufacturing capabilities, but also on the impact of climatic factors in the qualitative barley destined for the production of beer [14.1]. Currently no planting barley research is mainly focused on (two) areas in the Republic of Kosovo.These areas are: Dukagjini Plain and Kosovo Plain. Planting barley cultivars in these areas is based on a study that determines the impact of climatic factors, temperature moisture on barley for beer production qualities. For this reason it was thought up this study, which will get underway to study the suitability of the main varieties of barley for beer in Kosovo currently planted areas climatic conditionsdifferent ecological zones (Dukagjini Plain and 
Kosovo Plain). In these circumstances it is important to conduct studies for the evaluation of different varieties of barley on the main characteristics that define the quantity and quality of beer production [13, 17].From various studies it appears that the main characteristics of manufacturing malt from barley seeds are protein content and their energy to come on earth $[5,12]$. These features of seeds affected by growing conditions particularly in the grain formation stage (Schelling et al. 2003) [8, 7]. The impact of these conditions will be studied in two different climatic zones (Dukagjini Plain and Kosovo Plain) five different varieties of barley. The average yield achieved during the past three years is around $2.5-3.2 \mathrm{t} /$ ha. Kosovo's agro-climatic and pedological data, compared with the yields obtained in the culture of barley indicate that, potentially, the amount of barley stocks that can be produced are enormous production potential of barley cultivars that are grown in our conditions is over $8 \mathrm{t} /$ ha, while the use of this potential in the country's average level is $30-40 \%(2.5 \mathrm{t} / \mathrm{ha})$.

\section{Materials and methods}

Plots were organized lines and cultivated land area of real property Agricultural Institute of Kosovo in location Arbnesh, $6 \mathrm{~km}$ from Peja. Soil type, soil brown lesivuar on reddish sediments, and the altitude are 488 meters and the Plain of Kosovo (Pestova) where the nature of the soil is smonic, and altitude is 560 meters. Research of agronomic traits and quality of winter barley varieties (Hordeum vulgare L.) in growing conditions in Kosovo were made during the three years from 2010 to $2011 \quad$ and 2012. Planting is done with planter plots 80. Research undertaken over the years varieties are: Bingo, Vanessa, Zllatko, Rex and Esterel. Experiments are set according to the system block system with three replication in randomized [3,11]. Each experimental plot area is 10 $\mathrm{m} 2$ (10 m length x $1 \mathrm{~m}$ width). Depth of planting $3-5 \mathrm{~cm}$. Between Varieties will be left separating distance $30 \mathrm{~cm}$ and between iterations $50 \mathrm{~cm}$.

\subsection{Phenological parameters ( fenostages)}

Growth and development of the barley plant comprises and scrolled through some relevant biological stage, in which, under the influence of ecological factors, initial vegetative and generative organs are formed [2,6]. These stages: germination stage, brotherhood phase, establishment phase, the phase of the report, blooming and maturation.

- Germination stage - it was found that the optimum temperature for the transcription of this phase of barley germination ranges from $15-200 \mathrm{C}$.

- brotherhood phase - and agro climatic optimum conditions, when the values of daily temperatures range from $10-160 \mathrm{C}$ and optimum moisture, it begins 15 days after germination phase.

- Establishment phase - in the raising phase, in optimal conditions ecological first begins to extend and further increase nodusi (node) of the first stem.

- Phase charges - depending on the type, cultivar and seeds ecological, in a region in which the cultivated barley, for a period of 25 - 45 days after completion of the previous raise, the initial step of the report.

- $\quad$ Flowering stage - at this stage in optimal conditions of temperature of 17-260 C and humidity is the maximum formation of ears on the cob and optimal formation of flowers in ears (2-4).

- Stages of ripeness - After process polenizimit and fertilize the flowers in the ear of barley, begins with an intensity increase speed and full formation of all parts of the fruit (grain) of barley.

All of barley yellow plant, most of the leaves fall, and humidity in grains of barley is constant, 13-14\%

\section{Results and discussion}

After planting barley in plots immediately started tracking parameters such as the density of plants in experimental fields on the tenth day after planting which measurement results are present in Table 1. On the day of 10 (ten) after planting in all varieties of barley in plots has become the definition of plant density barley varie ty and cease it by counting three lines in length (3xlmetër), random system. On the day of 10 (ten) after planting in all varieties of barley has become the definition of plant density on the lines that counting three lines in length $(3 \mathrm{x} 1$ meter) with random system. Based on the data in table 1 and figure 1. Seen that varieties with high density over three year's research have variety Bingo average value of $82 \mathrm{~cm} .3 .1$. Count brotherhood

In the second decade of April, the three lines for each line is numbered all the primary and secondary follicles in order to determine the level of brotherhood varieties for research. The results achieved have presented in tab. 2 and Chart 2. Where we have put the number of seedlings average value over three years research has highest cultivar Vanesa 7.3 Regarding the stem height of all cultivars of barley tested were found positive differences in relation to the cultivars. Cultivars of barley plant density higher during the three-year research cultivar Zllatko while the greatest height of the stalk is found to cultivar Vanessa $(98 \mathrm{~cm}$ respectively $94 \mathrm{~cm})$ in both regions of the establishment of the experiment and the lowest Estereli $(76 \mathrm{~cm} 79 \mathrm{~cm}$ respectively), while other varieties have been hanging somewhere in between. In Table 4 we have the results of three years of research productivity where higher 
value is cultivar Vanesa and Zllatko. In vitro of barley cultivars were investigated following parameters: weight of 1000 seeds, hektolitare weight and productivity (Tab.5) and Graph 5.6. Also from the above table shows that there were differences between autumn barley cultivars tested in relation to standard cultivars. Autumn barley cultivars ma high weight of 1000 seeds is found to cultivar Bingo $(54.3 \mathrm{~g})$ while my low weight of 1000 seeds is found to cultivar Zllatko (40 $733 \mathrm{~g}$ and $41.95 \mathrm{~g}$ ). Weight hektolitare highest cultivar Vanesa 61.30. In Table 6. are given the results of\% moisture, protein, and starch percent. Higher protein presents cultivar Rex $13.73 \%$.

\section{Conclusions}

On the basis of the results obtained in research plots in 2010, 2011, and 2012 to the culture of barley in the fie ld of Dukagjinit (Arëbnesh-Peja) and in the field of Kosovo (Pestova) can conclude the following:

- Higher yields over the years in research have Vanesa plots and Zllatko in plain area of Kosovo (Pestova).

- In the area of Kosovo (Pestova) Vanessa and Zllatko has high yield $6972 \mathrm{~kg} / \mathrm{ha}$ and $6117 \mathrm{~kg} / \mathrm{ha}$, other varieties are also shown positive results, so my high yields generally given plane Kosovo

- Fenostages the development of barley varieties in the research we can conclude that approximately are approximate.

- agro-ecological conditions and production sites are researched very suitable for the cultivation of barley, but always taking into account the application of an agro and high care and

The agro-technical measures, in which special attention should be paid especially:

To explore cultivars with high potential manufacturer

Planting performed in optimal time

Soil analysis previously performed in terms of nutrient contents of major elements $(\mathrm{N}, \mathrm{P}, \mathrm{K})$

$>$ Use adequate and balanced nutrient fertilizers according to the content of nutrient elements in the earth, and planned yield

respected herbal circulation to eliminate the possibility of wintering potential attacks Harmful Biological Agents (ADB)

Application of Integrated Protection of barley culture but also the first culture

Using modern mechanist 
Table 1. Plant density in plots on day 10 (ten) after planting in two areas of 5 cultivars

Peja: Bingo, Vanesa, Zllatko, Rex, Esterel, Pestova: Bingo, Vanesa, Zllatko, Rex, Esterel

\begin{tabular}{lllllllllll}
2010 & 82 & 80 & 83 & 80 & 79 & 84 & 81 & 84 & 82 & 79 \\
2011 & 83 & 81 & 80 & 80 & 76 & 85 & 82 & 81 & 82 & 78 \\
2012 & 79 & 83 & 85 & 81 & 81 & 78 & 82 & 83 & 80 & 79 \\
\hline
\end{tabular}

Table 2. Number of seedlings (stalks) in two areas of 5 cultivars

Peja: Bingo, Vanesa, Zllatko, Rex, Esterel, Pestova: Bingo, Vanesa, Zllatko, Rex, Esterel

\begin{tabular}{lllllllllll}
2010 & 6 & 8 & 7 & 6 & 6 & 5 & 7 & 8 & 6 & 6 \\
2011 & 5 & 7 & 6 & 5 & 5 & 6 & 7 & 5 & 6 & 5 \\
2012 & 5 & 7 & 8 & 6 & 6 & 5 & 7 & 7 & 5 & 5 \\
\hline
\end{tabular}

Table 3. Plants density and height of the stalk in two areas of 5 cultivars

\begin{tabular}{|c|c|c|c|c|c|c|c|c|c|c|}
\hline \multicolumn{11}{|c|}{ Density $\left(\mathrm{m}^{2}\right)$} \\
\hline & Peja: Bingo, & Vanesa, & Zllatko, & Rex, & Esterel, & Pestova: Bingo, & Vanesa, & Zllatko, & Rex, & Esterel \\
\hline 2010 & 500 & 485 & 510 & 482 & 480 & 510 & 492 & 500 & 500 & 475 \\
\hline 2011 & 500 & 490 & 495 & 490 & 470 & 510 & 490 & 500 & 500 & 480 \\
\hline 2012 & 480 & 500 & 510 & 485 & 480 & 475 & 492 & 500 & 480 & 475 \\
\hline \multicolumn{11}{|c|}{ Height stalk (cm) } \\
\hline 2010 & 97 & 98 & 89 & 97 & 86 & 96 & 100 & 84 & 98 & 82 \\
\hline 2011 & 82 & 80 & 72 & 80 & 85 & 84 & 80 & 73 & 82 & 86 \\
\hline 2012 & 79 & 80 & 85 & 83 & 78 & 78 & 79 & 82 & 81 & 77 \\
\hline
\end{tabular}

Table 4. Yield $(\mathrm{kg})$ in two areas of the 5 cultivars

Peja: Bingo, Vanesa, Zllatko, Rex, Esterel, Pestova: Bingo, Vanesa, Zllatko, Rex, Esterel

\begin{tabular}{|c|c|c|c|c|c|c|c|c|c|c|}
\hline 2010 & 5.400 & 5.280 & 5.900 & 5.100 & 5.500 & 5.800 & 5.420 & 5.300 & 5.200 & 5.100 \\
\hline 2011 & 5.280 & 5.350 & 5.200 & 4.800 & 5.100 & 5.420 & 5.850 & 5.400 & 5.000 & 5.150 \\
\hline 2012 & 5.798 & 6.117 & 6.972 & 5.798 & 5.702 & 5.220 & 5.450 & 5.485 & 5.388 & 5.225 \\
\hline
\end{tabular}

Table 5. Weight 1000 seeds, weight hektolitare in two areas of the 5 cultivars 
Weight 1000 seeds $\%$

Peja: Bingo, Vanesa, Zllatko, Rex, Esterel, Pestova: Bingo, Vanesa, Zllatko, Rex, Esterel

\begin{tabular}{|c|c|c|c|c|c|c|c|c|c|c|}
\hline 2010 & 51.4 & 54.20 & 43.233 & 43.1 & 42.91 & 51.0 & 54.30 & 41.95 & 42.4 & 43.1 \\
\hline 2011 & 54.20 & 54.10 & 42.90 & 41.90 & 43.90 & 54.30 & 52.90 & 44.50 & 42.60 & 46.39 \\
\hline 2012 & 42.9 & 48.167 & 40.733 & 43.467 & 45.733 & 49.9 & 43.9 & 50.95 & 50.4 & 44.7 \\
\hline \multicolumn{11}{|c|}{ Weight hectoliter \% } \\
\hline 2010 & 57.8 & 58.85 & 59.3 & 57.2 & 59.55 & 57.6 & 59.90 & 59.90 & 59.3 & 57.2 \\
\hline 2011 & 58.85 & 61.30 & 60.10 & 64.56 & 55.50 & 59.90 & 61.90 & 61.20 & 65.42 & 56.85 \\
\hline 2012 & 59.683 & 58.017 & 59.633 & 59.767 & 59.55 & 55.1 & 58.45 & 57.075 & 57.3 & 58.25 \\
\hline
\end{tabular}

Table 6. Presentation of the results of Moisture $\%$ protein $\%$ and Starch $\%$ in two areas of the 5 cultivars

Humidity \%

Peja: Bingo, Vanesa, Zllatko, Rex, Esterel, Pestova: Bingo, Vanesa, Zllatko, Rex, Esterel

\begin{tabular}{lllllllllll}
2010 & 10.6 & 11.6 & 10.9 & 11.2 & 11.82 & 13.6 & 11.1 & 11.0 & 11.3 & 11.6 \\
2011 & 11.6 & 12.1 & 11.1 & 10.8 & 11.4 & 12.6 & 12.6 & 11.4 & 11.2 & 11.8 \\
2012 & 10 & 11.1 & \multicolumn{1}{c}{10.2} & 10 & 11.26 & 10.4 & 10.5 & 10.3 & 10.45 & 11.05 \\
\multicolumn{7}{c}{ Protein \% } & & & & \\
2010 & 13.4 & 12.5 & 13.20 & 13.6 & 13.4 & 13.4 & 12.6 & 13.25 & 13.8 & 13.1 \\
2011 & 13.4 & 12.7 & 13.2 & 13.2 & 12.9 & 13.9 & 13.8 & 13.4 & 13.8 & 13.2 \\
2012 & 13.73 & 12.9 & 13.35 & 13.73 & 13.4 & 13.35 & 12.9 & 13.35 & 13.73 & 13.4 \\
2010 & 60.2 & 60.2 & 60.4 & 60.4 & 60.5 & 60.35 & 60.35 & 60.55 & 60.45 & 60.2 \\
2011 & 60.1 & 60.1 & 60.1 & 60.2 & 60.3 & 60.2 & 60.15 & 60.4 & 60.35 & 60.1 \\
2012 & 62.5 & 63.6 & 62.6 & 62.5 & 61.4 & 60.85 & 62.15 & 60.85 & 61.55 & 61.2 \\
\hline
\end{tabular}

Graph 1. Plant density in plots on day 10 (ten) after planting in two areas of the 5 cultivars

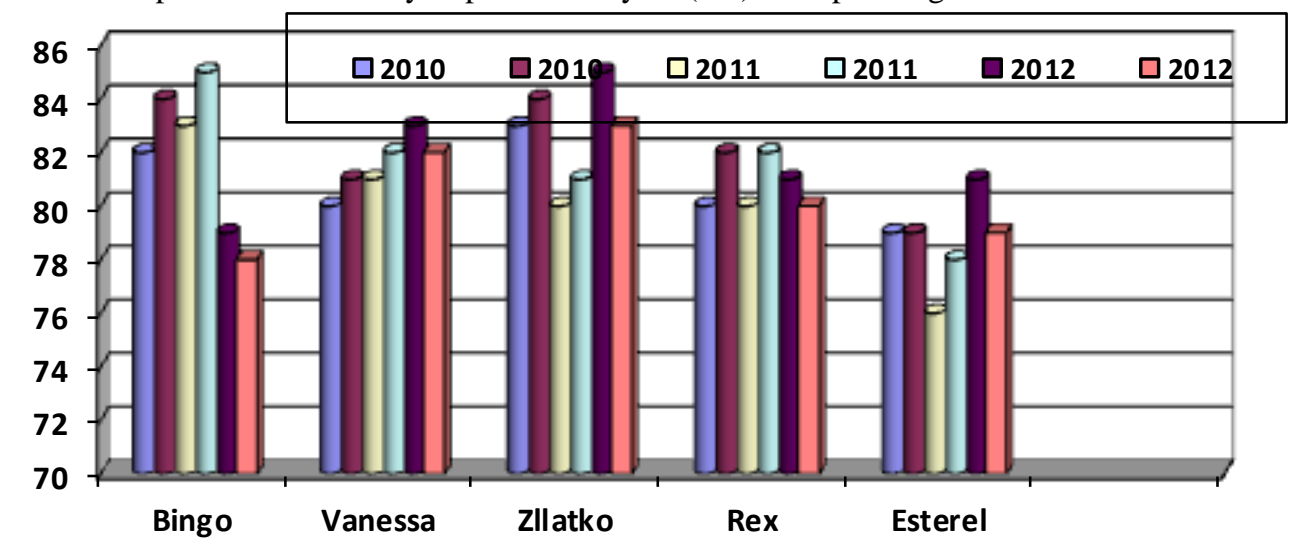

Graph 2.Number of seedlings (stalks) in two areas of the 5 cultivars 


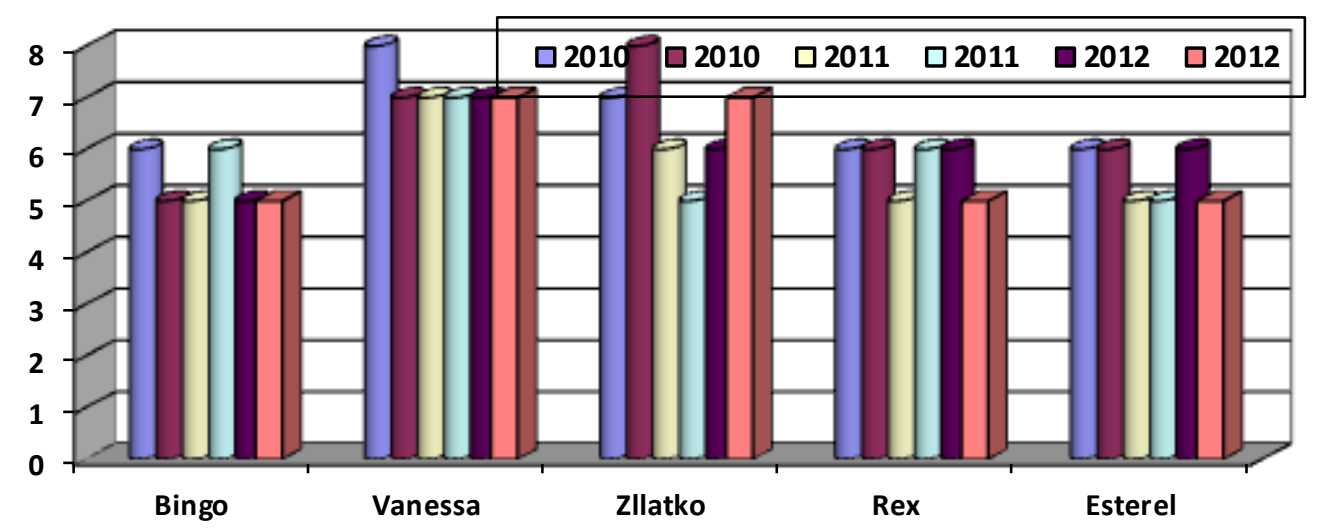

Graph 3. Plant density $\mathrm{m}^{2}$ in two areas of the 5 cultivars

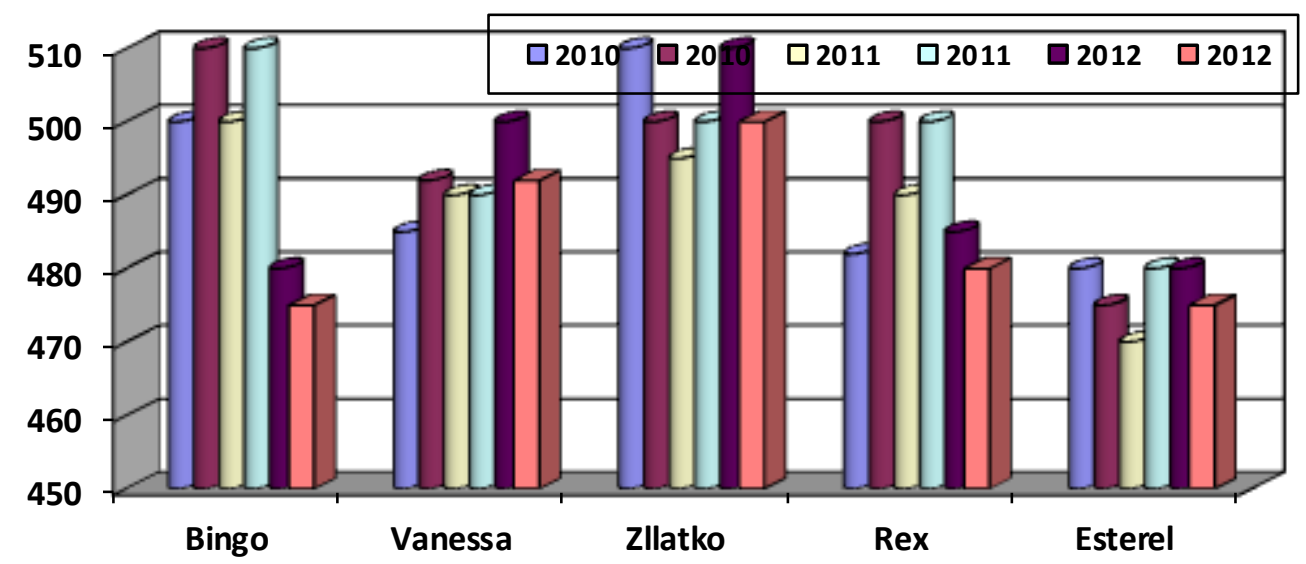

Graph 4. Yield $(\mathrm{kg})$ in two areas of the 5 cultivars

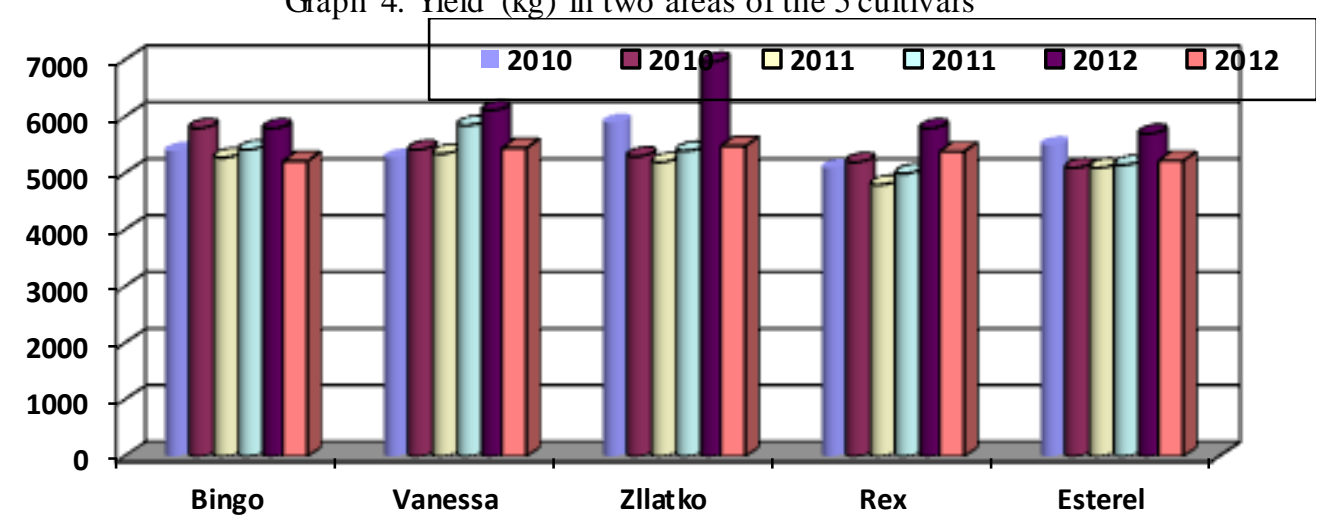

Graph 5. Weight 1000 seeds in two areas of the 5 cultivars 

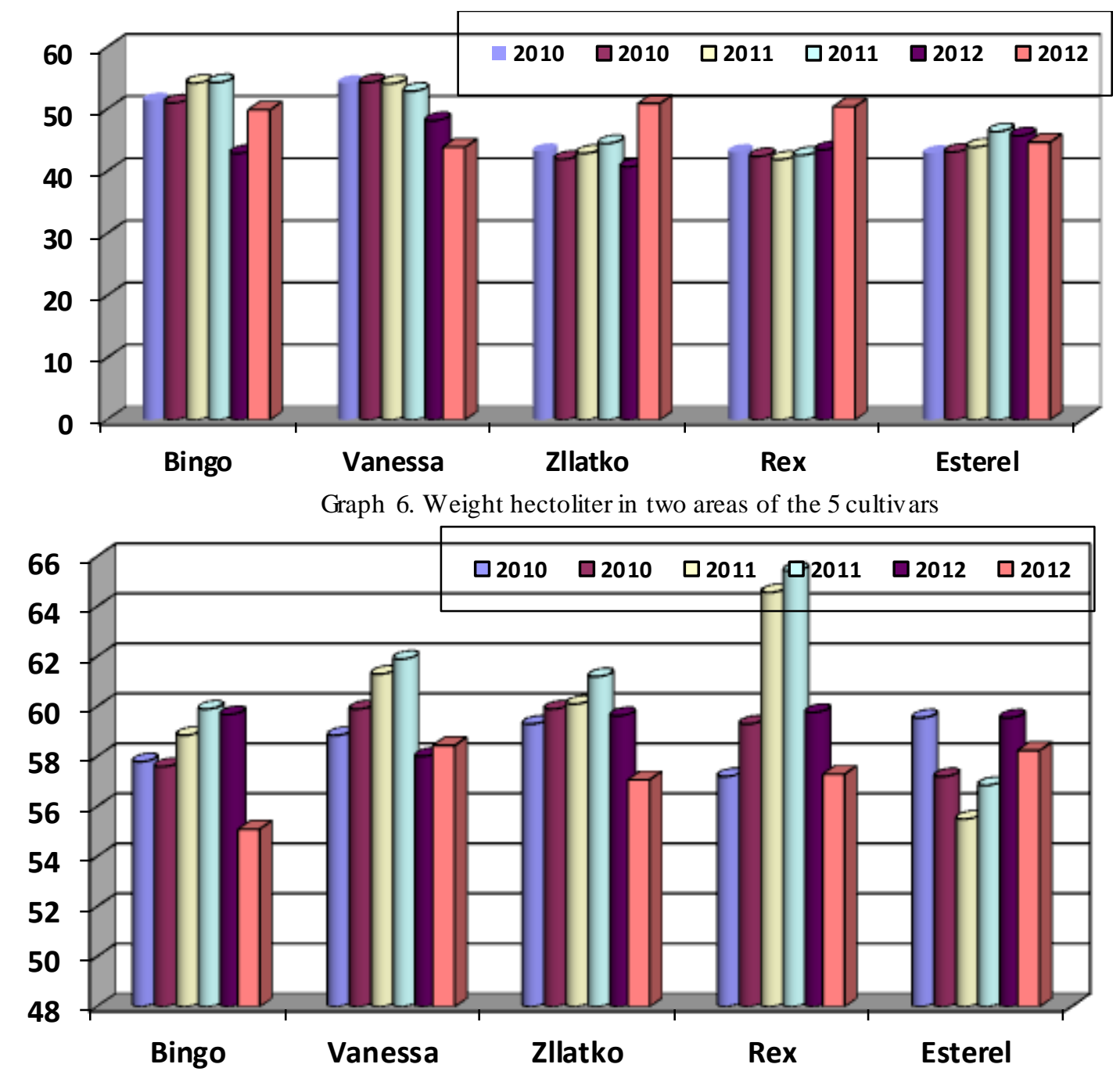

\section{References}

[1] Alley MM, Pridgen TH, Brann DE, Hammons JL, Mulford RL, (1997) Nitrogen fertilization of winter barley Priniples and Recommendations, Virginia Cooperative Extension, Crop \& Soil Environmetal. Scienes, 424-801. [2] Anderson OD, Haleford NG, Forde J, Yip RE, Shewry PR, (1988) Structure and analysis of the hight glutenin genes from triticum aestivum L cv Cheyenni in Miller TE, Koebner, (Eds) Proceedings $7^{\text {th }}$ International Wheat Genetics Symposium, Cambridge, pp. 735-740. 
[3] Anonym. (1995) Brabender, Betreib Anteilungen (1992-1995) Software Program loader, Duisburg, Germany, pp. 23-75.

[4] Bertholdsson N. O. (1999). Characterization of malting barley cultivars with more or less stable grain protein content under varying environmental conditions. European of Agronomy, 10, pp. 1-8.

[5] Bhuta, W, M, 2007. The effect of cultivaron the variation of spring wheat grain quality under drought conditions, Cereal Research Communications, Vol. 35, No. 4 pp 1609-1619.

[6] Conry M.J. (1997): Effect of fertilizer $\mathrm{N}$ on the grain yield and quality of spring malting barley grown on five contrsting soils in Irland. Boil. Environ 97:185-196.

[7] Costa j. M. - Boller, G.A.: 2001. Stability analysis of grain yield in barley (Hordeum vulgare) in US mid Atlantic region. Annals of Applied Biology. 139(1):137-143.

[8] Gaqesha S, Schuster, Weinfurtner, Narziss, (1990) Technology of production of malt, 432-84996-6, Beograd, pp.21-83.

[9] Kunze W, (2004) Technology brewing and malting, , 3 rd international edition VLB Berlin, 3-921690-49-8, page $32-49$.

[10] Macgregor AW, 1991. The effect of barley structure and composition on malt quality. Proceedings of the European brewery Convention, Lisbon, 37-50.

[11] Mckenzie, R.H. Middleton, A.B. \& Bremer, E. 2005. Fertilizion, seeding date, and seeding rate for malting barley yield and quality in southern Alberta. Canadian Yournal of Plant SCIENCE 85, 603-614.

[12] Munck L, (1991) Carlsberg research laboratory gample Carlsberg vej 10 DK-2500 valby, Copenhagen Denmark, Advances in Barley Quality Experiences \& Perspectives, 20,pp. 9-18.

[13] PapastylianouI. (1995): The effects of seed rate and nitrogen fertilization on yield and yield components of two-row barley. Eur.J.Agron., 4: 237-243.

[14] Schelling K, Born K, Weissteiner C, KühbauchË, (2003) Relationships between Yield and Quality

Parameters of Malting Barley (Hordeum vulgare L.) And Phonological and Meteorological Data Journal of Agronomy and Crop Science 189, 113-122, April

[15] Thoms on JR, (1979) an introduction to Seed Technology London, pp. 1-252 ISBN 0-249-44155-1 Record Number 19790380308.

[16] Van Gastel AJG, Bishaw Z, Niane AA, (2005) Syria, Technical guidelines for quality seed production. 2005 pp 23. ISBN 92-9127-181-1.

[17] Wallwork MAB., Jenner CF, Logue SJ, Sedgley M, (1998) South Australia 5064, Effect of high temperature during grain-filling on the structure of developing and malted barley grain, Article №.bo980721 Annals of Botany 82: 587-599, 1998. 